\title{
名神高速道路小牧インターチェンジの照明
}

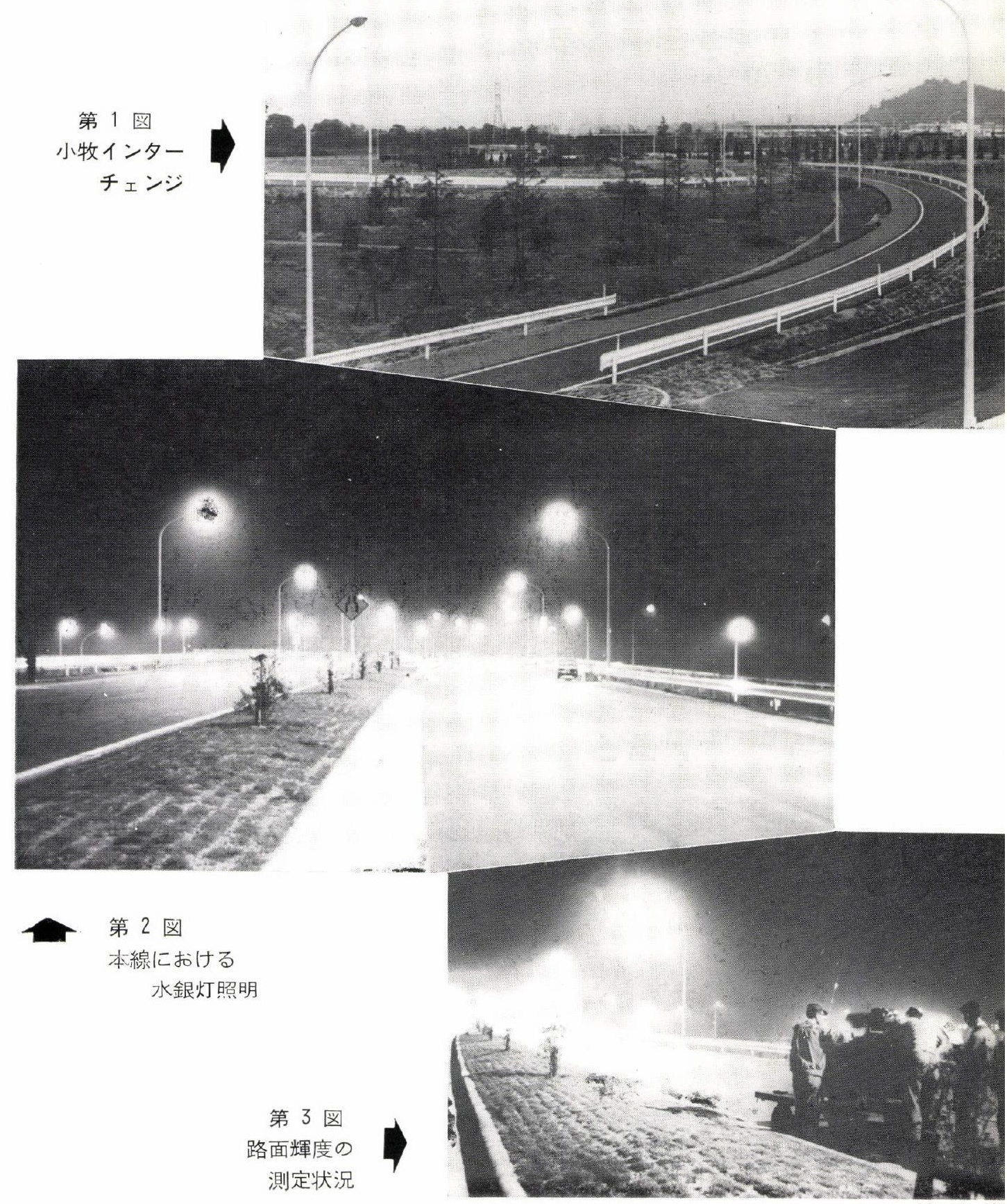


概 要

円本で最初の本格的高速 道路として「名神识速道 路」が，このほど小牧イン ターチェンジの完成により 全線開通した。

将来の東名向速避路との 接続品となるこの小牧イン ターチェンジには, けい光 水銀灯 $400 \mathrm{~W}$ ハイウェイ 器具( HP-314 形)を主体 に，特に灯具高さをランプ ウェイも含めてすべて 10 $\mathrm{m}$ とし, 標淮ポール間䍀

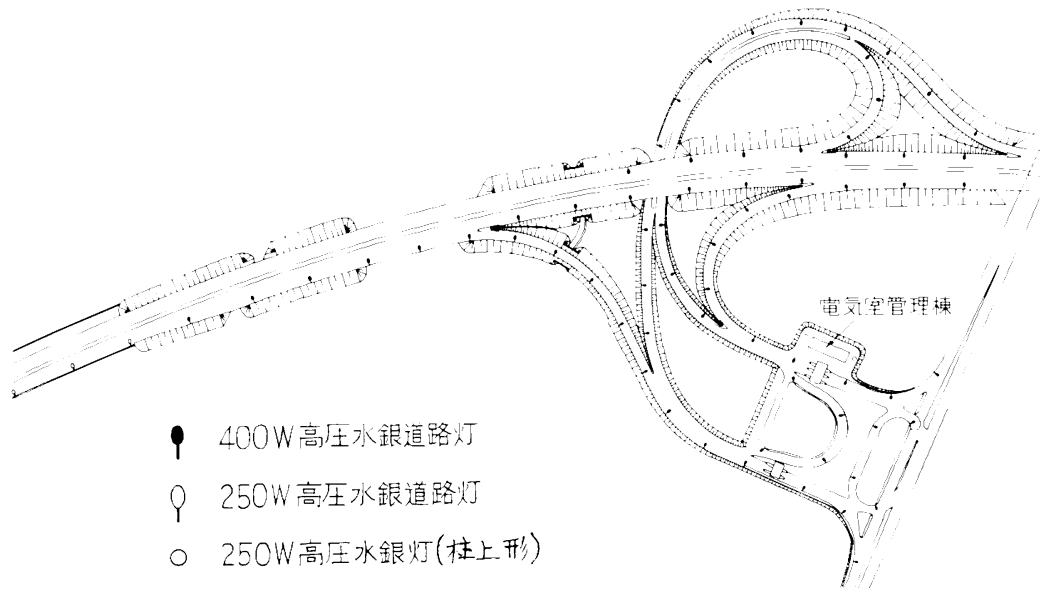
を約 $45 \mathrm{~m}$ に配置，グレア ○第 4 図灯具配置図

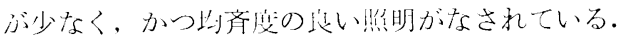

\title{
照 明 設 備
}

使用器具および灯数

$400 \mathrm{~W}$ 銀守色けい光水銀ランプ用ハイウェイ形道路 灯

69 灯

$250 \mathrm{~W}$ 銀白仙けい光水銀ランプ用ハイウェイ嵃道路 灯

\section{3 灯}

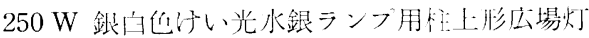

$40 \mathrm{~W} 2$ 灯用淔的けい光灯器! (陆橋卜)

灯具の配置は第 4 図のとおりである.

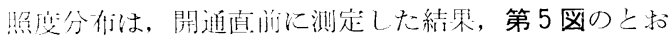
りでるった。

路田颣是の测定結果は下表のとおりであった。
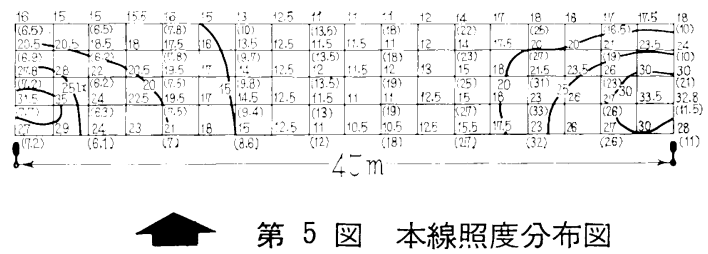

数值は水平面牵度を表わす。

た圪しカッコ内蛙鉛面照度を表わす。

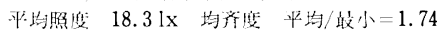

最大 $/$ 浐小 $=3.19$

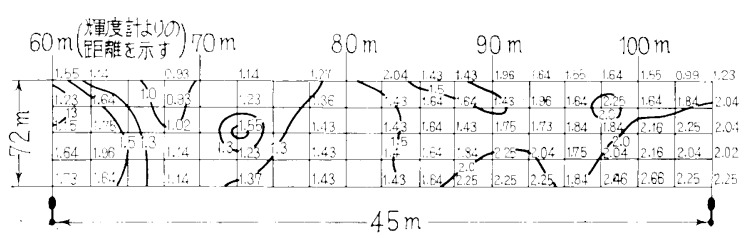

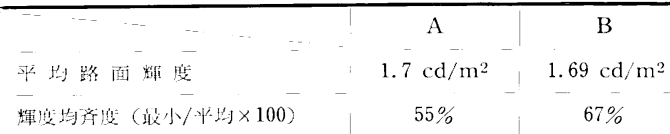

(付記)

1. 楎度部注 Spectra Telephotometer Model TEL-9 による.

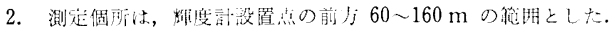

3. 測起点の人きをは，幅 $0.06 \sim 0.16 \mathrm{~m}$ の範明のけにある.

4. 輝度計の受光部法, 路面 $1: 1.5 \mathrm{~m}$ の吕さとした。

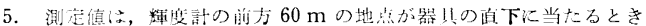
$\mathrm{A}$ ，中間に当たるとき $\mathrm{B}$ とに分けて站载した。

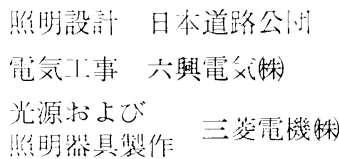

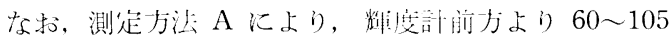

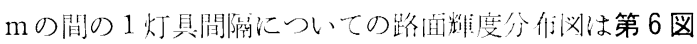
のと扤りである。

\author{
（資料提供日本追路公団） \\ 尃門会員 金 原 正 \\ (三菱笔機制) \\ 専門会員 小笠原 善 丸
}

